\title{
Maternal serum screening for Down's syndrome in early pregnancy
}

\author{
Nicholas J Wald, Howard S Cuckle, James W Densem, Kiran Nanchahal, Patrick Royston, \\ Tim Chard, James E Haddow, George J Knight, Glenn E Palomaki, Jacob A Canick
}

\begin{abstract}
The possibility of improving the effectiveness of antenatal screening for Down's syndrome by measuring human chorionic gonadotrophin concentrations in maternal serum during the second trimester to select women for diagnostic amniocentesis was examined. The median maternal serum human chorionic gonadotrophin concentration in $\mathbf{7 7}$ pregnancies associated with Down's syndrome was twice the median concentration in 385 unaffected pregnancies matched for maternal age, gestational age, and duration of storage of the serum sample. Measuring human chorionic gonadotrophin in maternal serum was an effective screening test, giving a lower false positive rate $(3 \%)$ at a $30 \%$ detection rate than that for maternal age $(5 \%)$ and the two existing serum screening tests, unconjugated oestriol $(7 \%)$ and $\alpha$ fetoprotein $(11 \%)$. The most effective screening results were obtained with all four variables combined; at the same $30 \%$ detection rate the false positive rate declined to $0.5 \%$.

The new screening method would detect over $60 \%$ of affected pregnancies, more than double that achievable with the same amniocentesis rate in existing programmes $(5 \%)$, and could reduce the number of children born with Down's syndrome in the United Kingdom from about 900 a year to about 350 a year.
\end{abstract}

\section{Introduction}

Down's syndrome is the most common congenital cause of severe mental retardation, with an incidence at birth of about 1.3 per 1000 . The current method of antenatal screening is to select women for a diagnostic amniocentesis on the basis of advanced age. Age is, however, a poor basis for screening and has had little impact on the incidence at birth. With age as a basis for screening only about $30 \%$ of all Down's syndrome pregnancies can be detected by carrying out amniocentesis on the $5 \%$ of women most at risk - that is, those aged 36 years or greater - though in practice fewer than $15 \%$ of affected pregnancies are detected because fewer than half of these older women actually have amniocentesis. ${ }^{1}$ Additional antenatal screening tests such as maternal serum measurements of $\alpha$ fetoprotein and unconjugated oestriol can increase the rate of detection to about $45 \%$ if the $5 \%$ of pregnant women at highest risk undergo amniocentesis. ${ }^{2}$

Recently Bogart and his colleagues found that human chorionic gonadotrophin concentrations in the maternal serum during the second trimester were significantly higher in pregnancies with chromosomally abnormal fetuses than in unaffected pregnancies. The study included 17 cases of Down's syndrome, of which $11(65 \%)$ had human chorionic gonadotrophin concentrations greater than $20 \mathrm{IU} / \mathrm{ml}$ compared with only one among 74 unaffected pregnancies $(1 \cdot 4 \%)$. These results encouraged us to assess whether human chorionic gonadotrophin measurement might be a worthwhile antenatal screening test for Down's syndrome used either alone or in combination with those already available.

\section{Methods}

Our study population consisted of women who attended the John Radcliffe Hospital, Oxford, for their antenatal care between 1973 and 1983. During this time a sample of serum was collected from each woman and stored at $-40^{\circ} \mathrm{C}$. In the antenatal serum bank that was accumulated in this way serum was available from all 77 singleton pregnancies associated with Down's syndrome. For each of these, five unaffected singleton control pregnancies were identified. The controls were matched with each case for maternal age (within the same year), gestational age (usually within one week), and duration of storage of sample (within one year). The serum from these 77 cases and 385 controls had been previously used to investigate unconjugated oestriol and $\alpha$ fetoprotein concentrations as antenatal screening tests for Down's syndrome. ${ }^{2}$

The samples were assayed for human chorionic gonadotrophin, with an immunoradiometric assay (Serono MAIA-clone kit calibrated to the first international reference preparation) at a dilution of 1 in 500 . All the assays were performed within three days, and cases and controls were always assayed in the same analytical batch without knowing whether the samples were from affected or unaffected pregnancies.

As the assays were performed under research conditions an estimate of the long term between batch assay variance was obtained, and this was added to the estimate of the observed variances of maternal serum human chorionic gonadotrophin concentrations in affected and unaffected pregnancies at each week of pregnancy to yield estimates of the standard deviations that would be found in routine practice. The long term variance was derived from two quality control specimens with mean human chorionic gonadotrophin concentrations of $22 \mathrm{IU} / \mathrm{ml}$ and $75 \mathrm{IU} / \mathrm{ml}$ that had been assayed 122 and 163 times, respectively, over six months.

To allow for the appreciable decline in maternal serum human chorionic gonadotrophin concentration in the second trimester of pregnancy, human chorionic gonadotrophin concentrations were expressed in multiples of the median (MoM) for unaffected pregnancies of the same gestational age. Because at some weeks of gestation there were too few pregnancies to provide reliable medians a regression of human chorionic gonadotrophin concentration on gestational age among unaffected pregnancies was 
performed to yield "regressed" normal medians. We used an exponential regression, incorporating a constant term, of the median human chorionic gonadotrophin concentration and median gestation (in days) for pregnancies in each completed week of pregnancy from 13 to 27 , weighted for the number of women at each week $(7,3,20,122,113,50,29,19,11,1,2,0,3$, 0 , and 5 , respectively). The equation of the regression

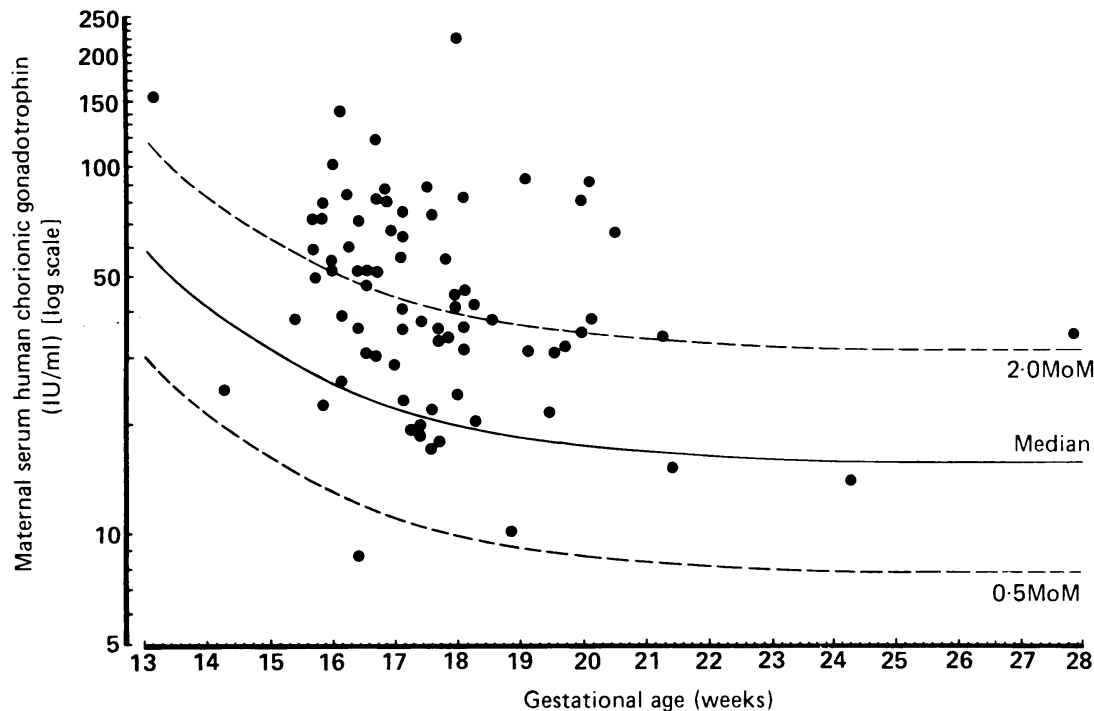

FIG 1-Human chorionic gonadotrophin concentrations in maternal serum in 77 pregnancies with Down's syndrome, and regressed medians derived from 385 unaffected pregnancies. MoM $=$ Multiple of median value for unaffected pregnancies of the same gestational age

TABLE I - Number (percentage) of Down's syndrome and unaffected pregnancies

\begin{tabular}{lcr}
\hline $\begin{array}{c}\text { Maternal serum } \\
\text { human chorionic } \\
\begin{array}{c}\text { gonadotrophin } \\
\text { concentration } \\
(\text { MoM })\end{array}\end{array}$ & $\begin{array}{c}\text { No }(\%) \text { of } \\
\text { Down's syndrome } \\
\text { pregnancies } \\
(\mathbf{n}=77)\end{array}$ & $\begin{array}{c}\text { No }(\%) \text { of } \\
\text { unaffected } \\
\text { pregnancies } \\
(\mathbf{n}=385)\end{array}$ \\
\hline$\geqslant 1.00$ & $66(86)$ & $195(51)$ \\
$\geqslant 1.25$ & $60(78)$ & $129(34)$ \\
$\geqslant 1.50$ & $56(73)$ & $96(25)$ \\
$\geqslant 1.75$ & $49(64)$ & $64(17)$ \\
$\geqslant 2.00$ & $42(55)$ & $40(10)$ \\
$\geqslant 2.25$ & $29(38)$ & $26(7)$ \\
$\geqslant 2.50$ & $25(32)$ & $17(4)$ \\
$\geqslant 2.75$ & $21(27)$ & $11(3)$ \\
& $17(22)$ & $8(2)$ \\
\hline
\end{tabular}

MoM=Multiple of median value for unaffected pregnancies of same gestational age.

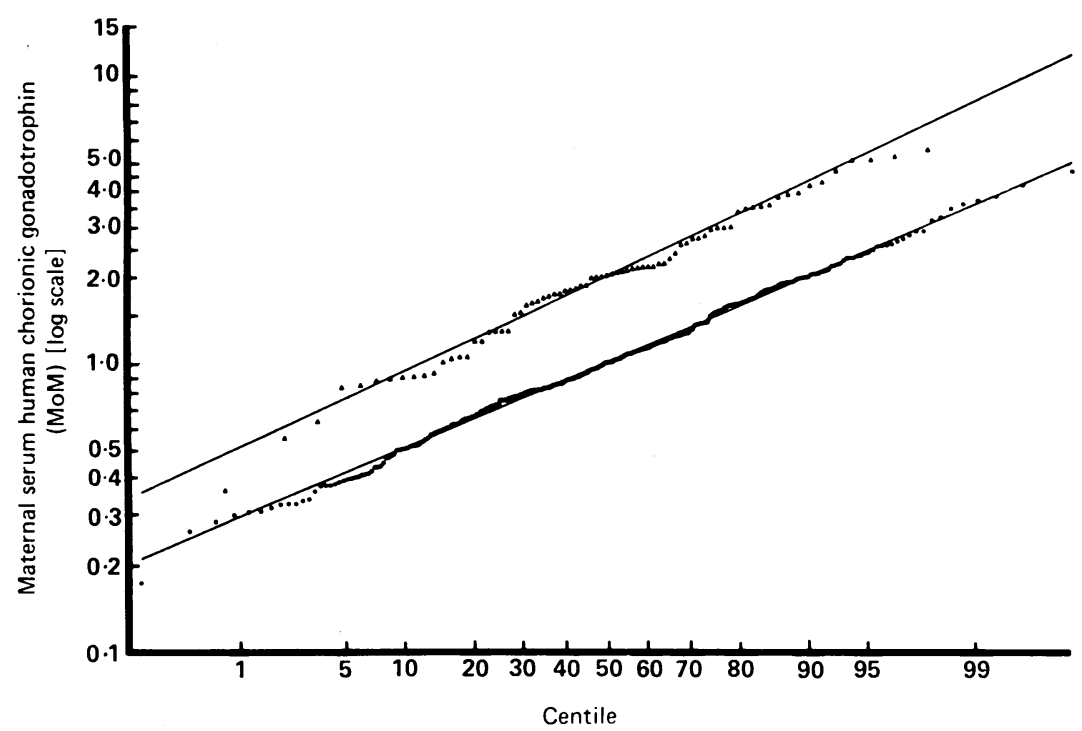

FIG 2-Probability plot of centiles of human chorionic gonadotrophin in maternal serum in Down's syndrome and unaffected pregnancies. Continuous lines are those defined by fitted Gaussian distributions (see statistical appendix). $M o M=$ Multiple of median for unaffected pregnancies of same gestational age

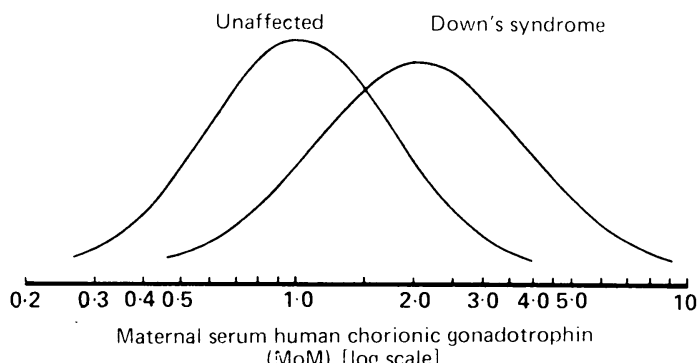

(:MoM) [log scale]

FIG 3-Gaussian frequency distributions of log maternal serum human chorionic gonadotrophin concentration in Down's syndrome and unaffected pregnancies, with standard deviations increased to allow for long term imprecisions in assays. MoM=Multiple of median for unaffected pregnancies of same gestational age

line was: human chorionic gonadotrophin concentra-

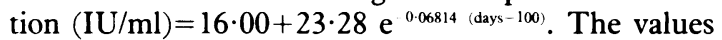
that were observed and those predicted from the regression line were very close: at 13-15 weeks they were $33 \mathrm{IU} / \mathrm{ml}$ and $31 \mathrm{IU} / \mathrm{ml}$, respectively, at $16-18$ weeks $22 \mathrm{IU} / \mathrm{ml}$ and $22 \mathrm{IU} / \mathrm{ml}$, at $19-21$ weeks $19 \mathrm{IU} / \mathrm{ml}$ and $18 \mathrm{IU} / \mathrm{ml}$, and at $22-27$ weeks $14 \mathrm{IU} / \mathrm{ml}$ and $16 \mathrm{IU} / \mathrm{ml}$.

The means and standard deviations used in the distributions were estimated from the observed medians and the ranges between the 10th and 90th centiles for the variables concerned. Following usual practice "detection rate" is defined as the proportion of affected pregnancies that gave positive results and "false positive rate" is defined as the proportion of unaffected pregnancies that gave positive results.

\section{Results}

MATERNAL SERUM HUMAN CHORIONIC GONADOTROPHIN

Figure 1 shows the individual human chorionic gonadotrophin concentrations for each pregnancy associated with Down's syndrome, together with the regressed median for unaffected pregnancies and lines corresponding to $0.5 \mathrm{MoM}$ and $2.0 \mathrm{MoM}$, which were roughly equivalent to the 10 th and 90 th centiles of the normal range. The precise values of these centiles were 0.51 and 2.01 , respectively. The median human chorionic gonadotrophin concentration in Down's syndrome pregnancies was $2.04 \mathrm{MoM}$, significantly higher than that in unaffected pregnancies $(p<0.001$, based on an analysis of variance of ranks within matched sets; $95 \%$ confidence interval 1.72 to 2.42 MoM). The 10th and 90th centiles for affected pregnancies were $0.90 \mathrm{MoM}$ and $4 \cdot 13 \mathrm{MoM}$, respectively.

Table I shows the observed numbers and proportions of affected and unaffected pregnancies with maternal serum human chorionic gonadotrophin values greater than or equal to specified values. Figure 2 is a probability plot of the human chorionic gonadotrophin concentrations (expressed in logarithms) for affected and unaffected pregnancies. The human chorionic gonadotrophin values for each group of pregnancies form a straight line, showing that they are distributed in a Gaussian manner. There was no significant deviation from the fitted Gaussian distributions ( $p=0.98$ for Down's syndrome and $p=0.56$ for unaffected pregnancies). Figure 3 , which shows the extent of discrimination between affected and unaffected pregnancies that would apply if this test were to be used in antenatal screening, shows the distributions, with standard deviations increased to allow for long term assay imprecision. The discrimination was greater than that achievable by screening using maternal age alone, maternal serum $\alpha$ fetoprotein concentration alone, or maternal serum unconjugated oestriol concentration alone. At human chorionic gonadotrophin cut off levels that would yield detection 
rates of $20 \%, 30 \%, 40 \%$, and $50 \%$, the estimated false positive rates would be $2 \%, 3 \%, 7 \%$, and $10 \%$, respectively. The corresponding false positive rates for screening using maternal age would be $2 \%, 5 \%, 11 \%$, and $19 \%$ using the age distribution of pregnancies for England and Wales in 1981-5 (see footnote to table 4 in Wald and Cuckle ${ }^{1}$ ); for screening using $\alpha$ fetoprotein measurement the false positive rates would be $6 \%$, $11 \%, 17 \%$, and $24 \%$, and for unconjugated oestriol, $4 \%, 7 \%, 11 \%$, and $16 \%$.

\section{COMBINING SCREENING TESTS}

When using several variables in combination to screen for a particular disorder it is necessary to

TABLE II - Median human chorionic gonadotrophin concentrations in Down's syndrome and unaffected pregnancies by maternal age and serum unconjugated oestriol and $\alpha$ fetoprotein concentrations

\begin{tabular}{lcc}
\hline & $\begin{array}{c}\text { Down's syndrome } \\
\text { pregnancies } \\
\text { MoM (No) }\end{array}$ & $\begin{array}{c}\text { Unaffected } \\
\text { pregnancies } \\
\text { MoM (No) }\end{array}$ \\
\hline $\begin{array}{cc}\text { Age (years): } \\
<30\end{array}$ & \\
$30-$ & $1.94(20)$ & $1.10(100)$ \\
$35-$ & $1.62(17)$ & $0.96(85)$ \\
$\geqslant 40$ & $2.11(19)$ & $0.95(95)$ \\
Unconjugated oestriol concentration (MoM): & $1.02(105)$ \\
$<0.60$ & $2.71(20)$ & \\
$0.60-$ & $1.88(20)$ & $1.25(19)$ \\
$0.75-$ & $1.85(18)$ & $1.21(36)$ \\
$\geqslant 0.90$ & $1.84(19)$ & $0.97(77)$ \\
4 Fetoprotein concentration $($ MoM): & $1.00(253)$ \\
$<0.60$ & $1.64(17)$ & $1.02(22)$ \\
$0.60-$ & $2.05(24)$ & $0.91(75)$ \\
$0.80-$ & $2.12(23)$ & $0.89(95)$ \\
$\geqslant 1.00$ & $2.24(13)$ & $1.10(193)$ \\
\hline Total & $2.04(77)$ & $1.02(385)$ \\
\hline
\end{tabular}

$\mathrm{MoM}=$ Multiple of median value for unaffected pregnancies of same gestational age.

TABLE UI-Probability of a 35 year old woman having a Down's syndrome term pregnancy according to selected maternal serum human chorionic gonadotrophin, unconjugated oestriol, and a fetoprotein concentrations

\begin{tabular}{|c|c|c|c|c|}
\hline \multirow{2}{*}{$\begin{array}{l}\text { Unconjugated } \\
\text { oestriol } \\
\text { concentration } \\
(\text { MoM })\end{array}$} & \multirow{2}{*}{$\begin{array}{c}\text { Human } \\
\text { chorionic } \\
\text { gonadotrophin } \\
\text { concentration } \\
(\mathrm{MoM})\end{array}$} & \multicolumn{3}{|c|}{$\alpha$ Fetoprotein concentration $(\mathrm{MoM})$} \\
\hline & & 0.4 & $1 \cdot 0$ & $2 \cdot 5$ \\
\hline $0 \cdot 4$ & $\left\{\begin{array}{l}0.5 \\
1.0 \\
2.0\end{array}\right.$ & $\begin{array}{l}1: 370 \\
1: 84 \\
1: 16\end{array}$ & $\begin{array}{l}1: 2800 \\
1: 480 \\
1: 69\end{array}$ & $\begin{array}{l}1: 22000 \\
1: 2800 \\
1: 310\end{array}$ \\
\hline $1 \cdot 0$ & $\begin{array}{l}0.5 \\
1.0 \\
2.0\end{array}$ & $\begin{array}{l}1: 820 \\
1: 330 \\
1: 110\end{array}$ & $\begin{array}{l}1: 4800 \\
1: 1400 \\
1: 360\end{array}$ & $\begin{array}{l}1: 28000 \\
1: 6400 \\
1: 1200\end{array}$ \\
\hline $1 \cdot 4$ & $\begin{array}{l}0.5 \\
1 \cdot 0 \\
2 \cdot 0\end{array}$ & $\begin{array}{l}1: 2200 \\
1: 1300 \\
1: 630\end{array}$ & $\begin{array}{l}1: 11000 \\
1: 4600 \\
1: 1700\end{array}$ & $\begin{array}{l}1: 52000 \\
1: 17000 \\
1: 4700\end{array}$ \\
\hline
\end{tabular}

MoM= Multiple of median value for unaffected pregnancies of same gestational age. assess the extent of correlation among the variables concerned. If two variables are perfectly correlated one adds nothing to the other in determining the risk of having the disorder; if they are completely unrelated each provides an independent measure of risk. If they are partially correlated there will be some independent information. We therefore examined the associations between human chorionic gonadotrophin and maternal age, unconjugated oestriol concentrations, and $\alpha$ fetoprotein concentrations in affected and unaffected pregnancies (table II). There was no evidence of an association between human chorionic gonadotrophin concentrations and maternal age, but there was a small negative association between human chorionic gonadotrophin and unconjugated oestriol concentrations. The relation between human chorionic gonadotrophin and $\alpha$ fetoprotein concentrations was less evident, but as unconjugated oestriol and $\alpha$ fetoprotein concentrations have been shown to be associated, ${ }^{2}$ and human chorionic gonadotrophin and unconjugated oestriol concentrations are associated, there probably is an underlying association. The correlation coefficients between the serum variables are given in the statistical appendix together with a description and validation of the statistical methods used to estimate a woman's risk of having an affected pregnancy from information on her age and biochemical test results.

Table III shows the risk of having a Down's syndrome term pregnancy according to selected values of the three biochemical screening tests as they would apply to a 35 year old woman. It shows how, if the results of any two tests are known, the third is still informative. For example, if a 35 year old woman had an $\alpha$ fetoprotein concentration of $1.0 \mathrm{MoM}$ and an unconjugated oestriol concentration of $0.4 \mathrm{MoM}$, the risk would be 1:2800 at a human chorionic gonadotrophin concentration of $0.5 \mathrm{MoM}$ and 1:69 at 2.0 MoM.

When screening with several tests simultaneously a difficulty arises because no single cut off level for each of the tests will be suitable; the cut off level for any one test will depend on the results of the others. A simple solution is to estimate each woman's risk of having a Down's syndrome pregnancy as in table III and to use this risk estimate as the screening variable in much the same way as if it were the result of a biochemical test. Table IV shows the estimated false positive rate associated with specified detection rates of Down's syndrome using maternal age together with various combinations of concentrations of human chorionic gonadotrophin, $\alpha$ fetoprotein, and unconjugated oestriol in maternal serum (see statistical appendix). The table shows the extra benefit of using different combinations of tests. If only two of the three biochemical tests are to be used $\alpha$ fetoprotein and human

TABLE IV - False positive rates corresponding to specified detection rates of Down's syndrome using maternal age and serum $\alpha$ fetoprotein, unconjugated oestriol, and human chorionic gonadotrophin concentrations alone or in combination ${ }^{\star}$

\begin{tabular}{|c|c|c|c|c|c|c|c|}
\hline \multirow[b]{2}{*}{$\begin{array}{l}\text { Detection rate }(\%) \text { of } \\
\text { Down's syndrome }\end{array}$} & \multicolumn{7}{|c|}{ False positive rate $(\%)$ for age with: } \\
\hline & $\begin{array}{l}\alpha \text { Fetoprotein } \\
\text { concentration }\end{array}$ & $\begin{array}{l}\text { Unconjugated } \\
\text { oestriol } \\
\text { concentration }\end{array}$ & $\begin{array}{l}\text { Human chorionic } \\
\text { gonadotrophin } \\
\text { concentration }\end{array}$ & $\begin{array}{l}\alpha \text { Fetoprotein and } \\
\text { unconjugated oestriol } \\
\text { concentrations }\end{array}$ & $\begin{array}{l}\alpha \text { Fetoprotein and } \\
\text { human chorionic } \\
\text { gonadotrophin } \\
\text { concentrations }\end{array}$ & $\begin{array}{l}\text { Unconjugated oestriol } \\
\text { and human chorionic } \\
\text { gonadotrophin } \\
\text { concentrations }\end{array}$ & $\begin{array}{l}\alpha \text { Fetoprotein, } \\
\text { unconjugated oestriol, } \\
\text { and human chorionic } \\
\text { gonadotrophin } \\
\text { concentrations }\end{array}$ \\
\hline 80 & 44 & 34 & 27 & 29 & 20 & 20 & 16 \\
\hline 75 & 37 & 27 & 21 & 23 & 15 & 15 & 12 \\
\hline 70 & 30 & 22 & 16 & 18 & 12 & 11 & 8.6 \\
\hline 65 & 25 & 18 & 12 & 15 & 8.8 & $8 \cdot 1$ & 6.4 \\
\hline 60 & 20 & 14 & $9 \cdot 5$ & 12 & $6 \cdot 7$ & $6 \cdot 0$ & $4 \cdot 7$ \\
\hline 55 & 16 & 11 & $7 \cdot 2$ & $9 \cdot 1$ & 5.0 & 4.4 & 3.4 \\
\hline 50 & 12 & 8.8 & $5 \cdot 4$ & $7 \cdot 0$ & $3 \cdot 7$ & $3 \cdot 2$ & $2 \cdot 5$ \\
\hline 45 & $9 \cdot 8$ & $6 \cdot 7$ & 3.9 & $5 \cdot 3$ & $2 \cdot 7$ & $2 \cdot 3$ & 1.7 \\
\hline 40 & $7 \cdot 3$ & $5 \cdot 0$ & $2 \cdot 8$ & 3.9 & 1.9 & 1.6 & 1.2 \\
\hline 35 & $5 \cdot 3$ & 3.7 & 1.9 & 2.8 & $1 \cdot 3$ & 1.0 & 0.8 \\
\hline 30 & $3 \cdot 6$ & 2.5 & $1 \cdot 2$ & 1.9 & 0.8 & 0.7 & 0.5 \\
\hline 25 & $2 \cdot 2$ & 1.6 & 0.8 & 1.2 & 0.5 & 0.4 & 0.3 \\
\hline 20 & 1.3 & 0.9 & 0.4 & 0.7 & 0.3 & 0.2 & 0.2 \\
\hline
\end{tabular}

${ }^{\star}$ Result is positive if risk of Down's syndrome is high when estimated from maternal age and results of biochemical test or tests. 
chorionic gonadotrophin concentrations is the pair of choice, as $\alpha$ fetoprotein concentration is of separate value in screening for neural tube defects and the performance of $\alpha$ fetoprotein and human chorionic gonadotrophin concentrations in combination is not much worse than that of unconjugated oestriol and human chorionic gonadotrophin concentrations in combination. The best overall results are, however, obtained by using all three tests together with maternal age. This yielded, for example, a detection rate of $60 \%$ with a false positive rate of $5 \%$.

The false positive rates shown in the table are subject to errors in estimation, the extent of which will depend on the numbers of pregnancies studied. We carried out a sensitivity analysis, varying the underlying statistical parameter (means, standard deviations, and correlation coefficients). This showed that our estimates are likely to be reasonably reliable. For example, in table $\mathrm{IV}$, in which the estimated false positive rate is shown to be $5 \%$, further studies would be unlikely to yield estimates outside the range $4-6 \%$.

Screening centres will need to know the effect of using different cut off levels of risk on the detection rates and false positive rates as well as on the probability of being affected given a positive result. Table $\mathrm{V}$ shows these rates for different combinations of screening variables with six selected cut off levels of risk. karyotypes that would otherwise be needed to obtain the same detection rate. For example, to achieve $60 \%$ detection, out of every 1000 women screened using age and all three biochemical tests 48 (47 unaffected and about one affected) would need an amniocentesis and a karyotype compared with 201 (200 unaffected and about one affected) using age and $\alpha$ fetoprotein concentration alone (table IV). The cost of 153 amniocenteses and karyotypes saved would be about five times higher than the cost of 1000 human chorionic gonadotrophin and unconjugated oestriol tests. Implementing such screening should be straightforward but will probably require computer software capable of interpreting combined test results.

Our results imply that maternal age should no longer be regarded as the primary screening variable; it is simply one of several variables that need to be used in combination for all pregnant women. For example, it would be illogical to offer amniocentesis to all women above a certain age and to restrict the use of the biochemical tests to younger women, as some may be inclined to do because of a reluctance to withhold amniocentesis from some women who would have it under current medical practice. If such a selective approach were adopted some older women with a fairly low risk would have an amniocentesis while some younger women with a higher risk would not.

The effectiveness of maternal serum screening for

TABLE V-Down's syndrome detection rate $(D R)$, false positive rate $(F P R)$, and odds of being affected given a positive result (OAPR) for maternal age and serum human chorionic gonadotrophin concentration alone or combined with $\alpha$ fetoprotein and unconjugated oestriol concentrations according to risk cut off level

\begin{tabular}{|c|c|c|c|c|c|c|c|c|c|c|c|c|}
\hline \multirow{3}{*}{$\begin{array}{l}\text { Risk cut off } \\
\text { level }\end{array}$} & \multicolumn{12}{|c|}{ Age and human chorionic gonadotrophin concentration } \\
\hline & \multirow[b]{2}{*}{$\mathrm{DR}(\%)$} & \multirow[b]{2}{*}{$\operatorname{FPR}(\%)$} & \multirow[b]{2}{*}{ OAPR } & \multicolumn{3}{|c|}{$\begin{array}{l}\text { With } \alpha \text { fetoprotein } \\
\text { concentration }\end{array}$} & \multicolumn{3}{|c|}{$\begin{array}{l}\text { With unconjugated oestriol } \\
\text { concentration }\end{array}$} & \multicolumn{3}{|c|}{$\begin{array}{l}\text { With } \alpha \text { fetoprotein and unconjugated } \\
\text { oestriol concentrations }\end{array}$} \\
\hline & & & & $\mathrm{DR}(\%)$ & $\operatorname{FPR}(\%)$ & OAPR & $\operatorname{DR}(\%)$ & FPR $(\%)$ & OAPR & $\mathrm{DR}(\%)$ & FPR $(\%)$ & OAPR \\
\hline $1: 100$ & 32 & 1.5 & $1: 36$ & 38 & 1.6 & $1: 34$ & 40 & 1.6 & $1: 31$ & 44 & 1.7 & $1: 29$ \\
\hline $1: 150$ & 39 & $2 \cdot 6$ & $1: 52$ & $45 t$ & 2.8 & $1: 48$ & 48 & $2 \cdot 7$ & $1: 45$ & 52 & $2 \cdot 8$ & $1: 42$ \\
\hline $1: 200$ & $45 t$ & $4 \cdot 0$ & $1: 69$ & 51 & $4 \cdot 0$ & $1: 62$ & 53 & 3.9 & $1: 58$ & 57 & 3.9 & $1: 54$ \\
\hline $1: 250$ & 49 & $5 \cdot 1$ & $1: 81$ & 56 & $5 \cdot 3$ & $1: 74$ & 57 & $5 \cdot 1$ & $1: 70$ & 61 & $5 \cdot 0$ & $1: 65$ \\
\hline $1: 300$ & 54 & $6 \cdot 6$ & $1: 97$ & 59 & 6.5 & $1: 86$ & 61 & $6 \cdot 2$ & $1: 81$ & 64 & $6 \cdot 1$ & $1: 75$ \\
\hline $1: 350$ & 56 & $7 \cdot 7$ & $1: 107$ & 63 & $7 \cdot 8$ & $1: 98$ & 63 & $7 \cdot 4$ & $1: 92$ & 67 & $7 \cdot 2$ & $1: 85$ \\
\hline
\end{tabular}

* Result is positive if risk of a Down's syndrome term pregnancy $\geqslant$ cut off risk.

†Differences between false positive rates for $\mathbf{4 5 \%}$ detection rate shown here and those in table IV are due to rounding. Exact detection rates are $45 \cdot 3 \%$ for age and human chorionic gonadotrophin concentration and $45 \cdot 4 \%$ for age and human chorionic gonadotrophin and $\alpha$ fetoprotein concentrations.

\section{Discussion}

Our data confirm the observation reported by Bogart et al that human chorionic gonadotrophin concentrations in maternal serum are high in Down's syndrome pregnancies. $^{3}$ The explanation for this finding is not known, but it may be due to fetuses with Down's syndrome (and their placentas) being immature, an explanation we have suggested for the low $\alpha$ fetoprotein and unconjugated oestriol concentrations found in affected pregnancies. ${ }^{4}$ Human chorionic gonadotrophin in maternal serum is derived from the placenta, and concentrations decline appreciably between about 10 and 20 weeks of pregnancy. If a fetus that had Down's syndrome were immature and this produced a human chorionic gonadotrophin concentration typical of pregnancies about three weeks earlier this would account for the observed difference in maternal serum human chorionic gonadotrophin concentrations between affected and unaffected pregnancies.

Antenatal sicreening programmes for Down's syndrome using maternal age and all three biochemical variables in combination would be cost effective. As we have indicated, an $\alpha$ fetoprotein test is likely to be performed routinely as part of an antenatal screening programme for neural tube defects. At any level of detection the extra cost of the human chorionic gonadotrophin and unconjugated oestriol tests would be much less than the cost of the amniocenteses and
Down's syndrome might be improved still further by ultrasound screening measuring, for example, fetal femur length as a complementary technique. ${ }^{56}$ If so, it would be necessary to allow for correlations between the ultrasound measures and the serum markers, as they may not be independent measures of risk.

Our results indicate that it is now possible to screen pregnant women for Down's syndrome using maternal age and the results of simple blood tests and thereby identify about $60 \%$ of all affected pregnancies within a group comprising about $5 \%$ of all pregnancies. Such a policy would not require extra resources for diagnostic procedures as in many existing screening programmes based on maternal age alone resources have already been provided to ensure that $5 \%$ of all women can have an amniocentesis and a fetal chromosome analysis. The new policy, if adopted generally, would have the potential to reduce the number of babies born with Down's syndrome in the United Kingdom from about 900 a year to about 350 .

We thank Professor Eva Alberman and Professor Michael Marmot for their helpful comments, and Professor Sir Alec Turnbull for his help and support during our work in Oxford, when the antenatal serum bank used in this study was collected.

Screening for Down's syndrome with assays of unconjugated oestriol is subject to International Patent Application PCT/GB88/00557. 


\section{Appendix}

Method of estimating the risk of a Down's syndrome term pregnancy-The risk of a Down's syndrome term pregnancy for women of a given age was estimated with the equation in the footnote to table I in Cuckle $e t a l$ and the risk expressed as an odds ratio. This odds ratio was multiplied by the relevant likelihood ratio to yield the woman's risk given her age and the results of the biochemical variables used. The relevant likelihood ratio was derived from the appropriate univariate (if only one biochemical variable were used), bivariate (if two were used), or trivariate (if all three were used) Gaussian frequency distributions of unconjugated oestriol concentration, $\log \alpha$ fetoprotein concentration, and log human chorionic gonadotrophin concentration. The likelihood ratio was the height of the Gaussian distribution for the Down's syndrome pregnancies divided by the height of the Gaussian distribution for the unaffected pregnancies at the particular value or values of the variable or variables concerned.

Parameters of distributions-Table VI shows the values of the parameters of the distributions of the serum screening variables.

TABLE VI - Statistical variables of distributions of unconjugated oestriol concentrations, log human chorionic gonadotrophin concentrations, and $\log \alpha$ fetoprotein concentrations in Down's syndrome pregnancies and unaffected pregnancies

\begin{tabular}{|c|c|c|c|}
\hline Variable & Biochemical variable & $\begin{array}{l}\text { Down's syndrome } \\
\text { pregnancies }\end{array}$ & $\begin{array}{l}\text { Unaffected } \\
\text { pregnancies }\end{array}$ \\
\hline \multirow[t]{3}{*}{ Mean } & Log human chorionic gonadotrophin concentration & $0 \cdot 3096$ & 0.0073 \\
\hline & Unconjugated oestriol concentration & $0.73^{\star}$ & $1 \cdot 00^{\star}$ \\
\hline & $\log \alpha$ fetoprotein concentration & $-0 \cdot 1427^{\star}$ & $0.0000^{\star}$ \\
\hline \multirow[t]{3}{*}{ Standard deviation } & Log human chorionic gonadotrophin concentration & 0.2588 & $0 \cdot 2342$ \\
\hline & Unconjugated oestriol concentration & $0 \cdot 26^{\star}$ & $0 \cdot 27^{\star}$ \\
\hline & $\log \alpha$ fetoprotein concentration & $0.2052^{\star}$ & $0.2024^{\star}$ \\
\hline \multirow[t]{5}{*}{ Correlation coefficient } & Log human chorionic gonadotrophin- & & \\
\hline & unconjugated oestriol concentration & $-0 \cdot 25$ & -0.08 \\
\hline & Unconjugated oestriol concentration-log $\alpha$ & 0.14 * & $0 \cdot 13^{\star}$ \\
\hline & $\log \alpha$ fetoprotein concentration-log human chorionic & & \\
\hline & gonadotrophin concentration & $0 \cdot 14$ & 0.05 \\
\hline
\end{tabular}

^Derived from Wald et al.

Before allowing for long term variance between assays the standard deviations of human chorionic gonadotrophin concentrations in affected and unaffected pregnancies were 0.2582 and 0.2336 , respectively, and the correlation coefficients between log human chorionic gonadotrophin and unconjugated oestriol in affected and unaffected pregnancies were $-0.29(p=0.01)$ and $-0.08(p=0 \cdot 10)$, respectively; for $\log$ human chorionic gonadotrophin concentration and $\log \alpha$ fetoprotein excluding three controls who had outlying $\alpha$ fetoprotein concentrations.

Fit of data to Gaussian distributions - Maternal serum $\log \alpha$ fetoprotein concentrations fit a Gaussian distribution well within the range $0 \cdot 40-2 \cdot 50 \mathrm{MoM}^{7}$; unconjugated oestriol concentrations fit a Gaussian distribution well within the range $0 \cdot 40-1 \cdot 40 \mathrm{MoM}$; and log human chorionic gonadotrophin concentrations fit a Gaussian distribution well over the whole range of values (fig 2). The Shapiro-Wilk W test applied to squared radii as described by Royston ${ }^{8}$ was used to test for any deviations of the observed unconjugated oestriol concentration, log human chorionic gonadotrophin concentration, and $\log \alpha$ fetoprotein concentration from each bivariate or trivariate Gaussian distribution. There was no significant deviation from, firstly, the bivariate Gaussian distributions of unconjugated oestriol concentration and log human chorionic gonadotrophin concentration $(p=0.55$ for affected and $p=0.89$ for unaffected pregnancies); log human chorionic gonadotrophin concentration and log $\alpha$ fetoprotein concentration $(p=0 \cdot 20$ for affected and $\mathrm{p}=0.88$ for unaffected; and unconjugated oestriol concentration and $\log \alpha$ fetoprotein concentration $(0.76$ for affected and $p=0.10$ for unaffected); and, secondly, the trivariate Gaussian distributions $(p=0.79$ for affected and $p=0.60$ for unaffected) after excluding 13 controls who had outlying values, five who had extreme $\alpha$ fetoprotein concentrations, and eight who had extreme unconjugated oestriol concen- trations. These would not affect our estimates of risk because they were outside the ranges within which the fitted distributions were used to estimate risk.

Estimating detection rate and false positive rate using risk as a screening variable - The distribution of risk in Down's syndrome and unaffected pregnancies was found by numerically integrating the distribution of age and the appropriate univariate, bivariate, or trivariate Gaussian density functions over a grid of values of age and the corresponding biochemical variables. The risk associated with $\alpha$ fetoprotein concentrations outside the range $0 \cdot 40-2 \cdot 50 \mathrm{MoM}$ was taken to be equal to the value at the nearest endpoint of the range; similarly for unconjugated oestriol concentrations outside the range 0.40-1.40 MoM. The distribution of ages in Down's syndrome and unaffected pregnancies was derived by applying the age specific risk of a Down's syndrome term pregnancy to the number of pregnant women of different ages in England and Wales in 1981-5.

1 Wald NJ, Cuckle HS. Recent advances in screening for neural tube defects and Down syndrome. In: Rodeck C, ed. Bailliere's clinical obstetrics and gyna cology. International practice and research. Vol 1. Fetal diagnosis of genetic defects. London: Baillière Tindall, 1987:649-76.

2 Wald NJ, Cuckle HS, Densem JW, et al. Maternal serum unconjugated oestrio as an antenatal screening test for Down's syndrome. Br $\mathcal{f}$ Obstet Gynaecol 1988:95:334-41.

3 Bogart MH, Pandian MR, Jones OW. Abnormal maternal serum chorionic gonadotrophin levels in pregnancies with fetal chromosome abnormalities. gonadotrophin levels in pregnat Diagn 1987;7:623-30.

4 Canick JA, Knight GJ, Palomaki GE, Haddow JE, Cuckle HS, Wald NJ. Low second trimester maternal serum unconjugated oestriol in pregnancies with second trimester maternal serum unconjugated oestriol
Down's syndrome. Br $\mathcal{Y}$ Obstet Gynaecol 1988;95:330-3.

5 Benacerraf BR, Gelman R, Frigoletto FD. Sonographic identification of second-trimester fetuses with Down's syndrome. N Engl f Med 1987;317: $1371-6$

6 Lockwood C, Benacerraf BR, Krinsky A, et al. A sonographic screening method for Down syndrome. Am f Obstet Gynecol 1987;157:803-8.

7 Cuckle HS, Wald NJ, Thompson SG. Estimating a woman's risk of having a pregnancy associated with Down's syndrome using her age and serum alphafetoprotein level. Br f Obstet Gynaecol 1987; 94:387-402.

8 Royston JP. Some techniques for assessing multivariate normality based on the Shapiro-Wilk W. Applied Statistics 1983;32:121-33.

(Accepted 22 fune 1988)

\section{ONE HUNDRED YEARS AGO}

The Paris correspondent of the Daily Telegraph narrates a case illustrating the well-known fact that in a semiunconscious condition illusions are easily produced which may have disastrous results. A man, and a woman with her young infant, were the sole occupants of a compartment in the train running from Lille to Paris. It was evening, and the man fell sound asleep; when he partially awoke, the woman was feeding her infant from a bottle of milk. The half-awakened traveller appeared greatly frightened and shrank into the corner; soon he screamed and cried for assistance, and finally pulled the alarm-bell, and, opening the door, he fled to a neighbouring carriage, to which he clung. He subsequently stated that he had gone to sleep, when he was suddenly awakened by a lady who, with menacing gestures, pointed a revolver at his head. He called out for help, and effected his escape from his would-be murderess. When seen he was "all of a tremble," and he believed fully that, but for his promptitude, he would have been assassinated. It appears that he mistook the baby's bottle for a revolver. The case was investigated by the police, and there appears no doubt of its authenticity. Such cases of mental terror and illusions on suddenly awaking from sleep are common among children, but do not often occur in adults; but when they do occur in a severe form important results may follow, as in the case narrated. In children such conditions often lead to permanent impressions on the brain, producing attacks of recurring mental terror and consequent brain exhaustion. (British Medical fournal 1888;ii:135) 